\title{
EXAMINATION OF FRESHWATER PEAT PRETREATMENT METHODOLOGY
}

\author{
JOHN B WILLIAMS \\ Radiocarbon Laboratory, University of Pittsburgh \\ Pittsburgh, Pennsylvania 15238
}

\begin{abstract}
Preparation techniques used in dating freshwater peat were evaluated and compared using a homogeneous sample. This paper details various approaches to pretreatment of this material and presents the resultant ${ }^{14} \mathrm{C}$ dates. General trends in the results are discussed.
\end{abstract}

\section{INTRODUCTION}

In prior work done by this laboratory, inconsistencies between stratigraphic and radiocarbon date sequences have been observed in freshwater peats. There is no evidence that bioturbation, climatic or geological events influence this situation or that irregularities in dating seem confined to one laboratory (Polach \& Singh, 1980).

The organic composition of freshwater peat material is diversified, and thus, difficult to characterize, but the matrix is composed of a high percentage of material suitable for radiocarbon analysis. Improvements in pretreatment methodology would increase the usefulness of dates acquired from freshwater peat.

\section{SAMPLING}

Sample material consisted of a $0.03 \mathrm{~m}^{3}$ block of freshwater peat collected in April 1986 from an exposure formed by tidal erosion of a bog located on the north side of Carrying Place Cove, South Lubec, Maine (Fig 1). The sampling (by H W Borns, Jr, University of Maine) was made $210 \mathrm{~cm}$ below the surface of the bog and $90 \mathrm{~cm}$ above the level of the modern beach (Fig 2). The beach surface under the bog is overlain by marine clay. The sample was removed in a $90 \mathrm{~cm} \times 30 \mathrm{~cm} \times 10 \mathrm{~cm}$ section because of frozen conditions beyond the $10 \mathrm{~cm}$ depth. The sample's age, based on previous dates in the region, was estimated to be $2000 \mathrm{BP}$. After collection, the sample was packaged in plastic and sent to the Smithsonian Institution Radiocarbon Laboratory, where studies were delayed until re-establishment of the laboratory at the University of Pittsburgh in the early months of 1987.

The only sources of contamination conceived or observed are from post-depositional root penetration by active plant life, bacterially generated humic acid and saltwater spray. The geologic structure of the region is predominately granite with little limestone and no possibility of contact with fossil fuel sources. In addition, sources of agricultural runoff are distant, vehicular traffic in the area is sparse, oil spills on the beach are not known and dumping is not evident. 


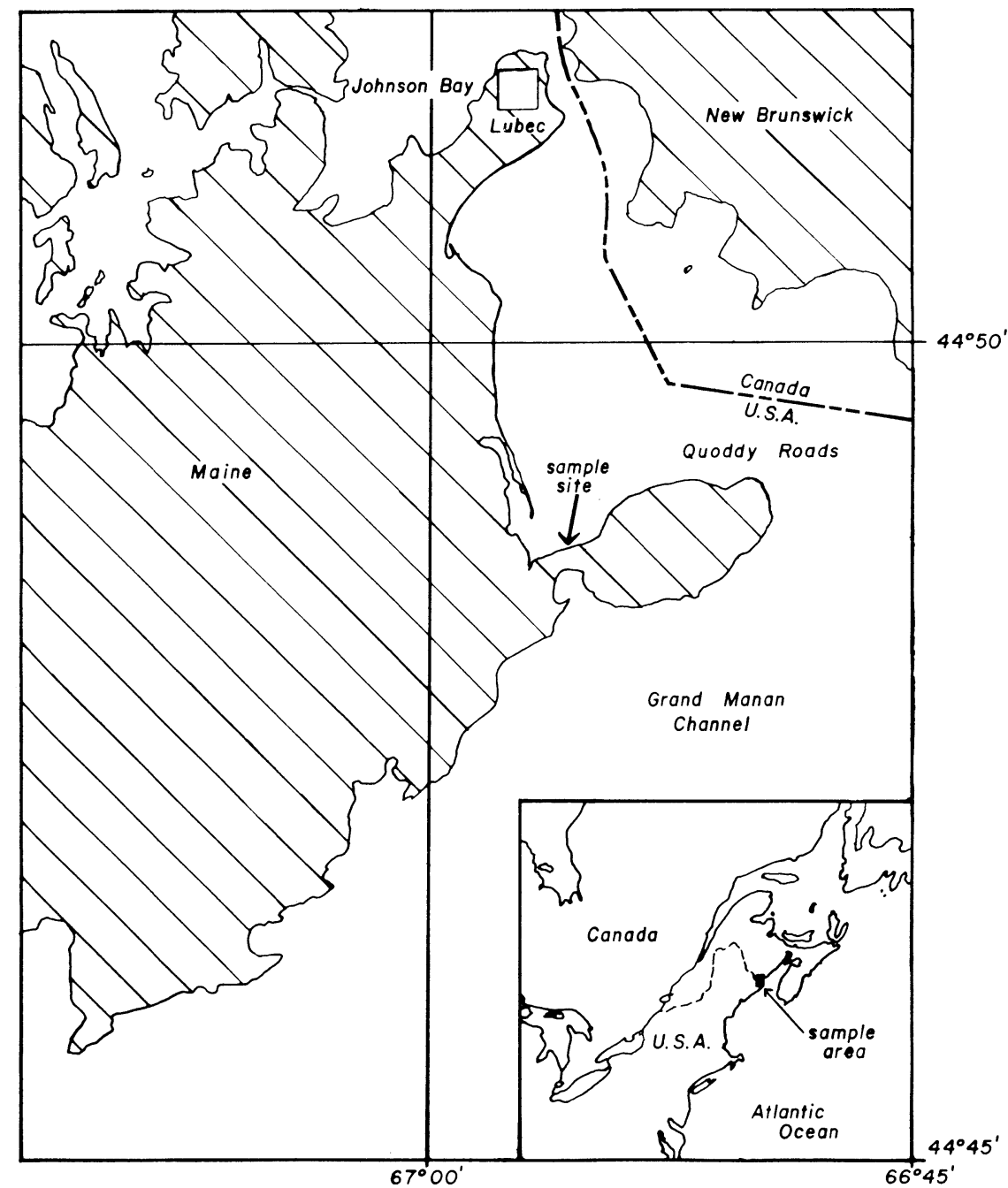

Fig 1. Map of South Lubec, Maine area with inset of the northeastern United States and southeastern Canada 


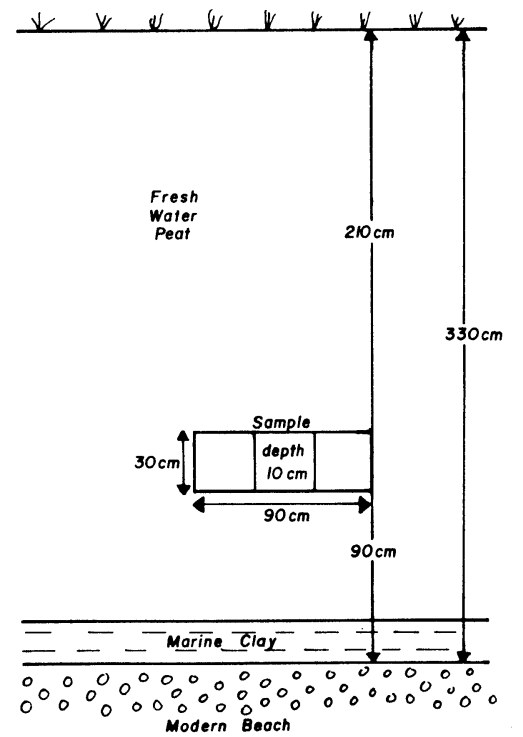

Fig 2. Peat exposure, Carrying Place, South Lubec, Maine

\section{METHODS}

Initially, the peat block was manually broken into small pieces and washed in $4000 \mathrm{ml}$ beakers with deionized water. After sieving, it was oven dried at $90^{\circ} \mathrm{C}$ for a period of five days. The material was then twice ground (particle size $<1000 \mu \mathrm{m}$ ) and homogenized by vigorous shaking and stirring.

All subsequent study was made using the homogenized peat in $10-50 \mathrm{~g}$ fractions. After the selected method of pretreatment was completed, the sample was positioned in a vycor tube and burned in oxygen. The product $\mathrm{CO}_{2}$ was captured with liquid nitrogen and purified, then reduced to the laboratory counting gas $\left(\mathrm{CH}_{4}\right)$ using hydrogen, pressure and a Ru catalyst at $400^{\circ} \mathrm{C}$. Upon completion of separation and purification, the sample $\mathrm{CH}_{4}$ was counted in one of the laboratory's five gas proportional counters (Stuckenrath \& Mielke, 1972) for periods totaling 4000-10,000 min at $100 \mathrm{~min}$ intervals. Mass spectrometer samples $\left(\mathrm{CO}_{2}\right)$ were taken in $10 \mathrm{ml}$ break seal tubes and sent to the Stable Isotope Laboratory at Case Western Reserve University for analysis.

The focus of investigation for the first set of samples was the effect of changes in $\mathrm{NaOH}$ concentration during pretreatment. The first sample (PITT-9000) was not pretreated and the next (PITT-9001) was only allowed to stand overnight in $400 \mathrm{ml}$ 2. ON HCl. Nine samples (PITT-9002 to -9008 , -9014 to -9015 ) were boiled for $15 \mathrm{~min}$ in $\mathrm{NaOH}$ with concentrations between $0.1 \% \mathrm{~W} / \mathrm{W}$ and $12.0 \% \mathrm{~W} / \mathrm{W}$. After $\mathrm{NaOH}$ treatment, each of these samples (except PITT-9002) was allowed to stand in $400 \mathrm{ml} 2.0 \mathrm{~N} \mathrm{HCl}$ overnight. Samples were vacuum filtered and washed with $1000 \mathrm{ml}$ deionized water after both base and acid treatment and then dried for two days at $90^{\circ} \mathrm{C}$ following the second filtration. 
With the second group of samples, parameters other than reagent strength were varied. Changes were made in length of humate extraction time, number of extractions (Kigoshi, Suzuki \& Shiraki, 1980), separation methods and washing technique. The multiple extraction sample (PITT9013) was washed and filtered after each $\mathrm{NaOH}$ boil, then treated with $\mathrm{HCl}$ after the final extraction (PITT-9013D). PITT-9012 was filtered and washed after $2.0 \% \mathrm{NaOH}$, then mixed with $500 \mathrm{ml}$ deionized water and centrifuged to obtain the B fraction. After $\mathrm{NaOH}$, all samples were acidified, filtered, washed and dried as detailed above.

The final group (PITT-9016 to -9019) was subjected to cellulose extraction techniques using sodium chlorite $\left(\mathrm{NaClO}_{2}\right)$ (from $\mathrm{H}$ A Polach, 1970) and sodium hypochlorite $(\mathrm{NaClO})$. With $\mathrm{NaClO}_{2}$, a $50 \mathrm{~g}$ sample was mixed into $2000 \mathrm{ml}$ deionized water and maintained between $70^{\circ} \mathrm{C}$ and $80^{\circ} \mathrm{C}$. The $\mathrm{pH}$ of the mixture was lowered to $\mathrm{pH}=2$ with $\mathrm{HCl}$ and constant mechanical stirring was implemented. A total of $100 \mathrm{~g} \mathrm{NaClO}_{2}$ was added in $5.0 \mathrm{~g}$ increments, with each addition occurring after the previous reaction had subsided. The $\mathrm{pH}$ was monitored after every third addition and readjusted to $\mathrm{pH}=2$. After completion, indicated by a straw-colored appearance, the sample was vacuum filtered, washed with $2000 \mathrm{ml}$ deionized water and then dried for two days at $90^{\circ} \mathrm{C}$. The procedure was also performed using $1000 \mathrm{ml} 5.0 \% \mathrm{~W} / \mathrm{W} \mathrm{NaClO}$ (in $10 \mathrm{ml}$ portions) with a $2000 \mathrm{ml}$ sample mixture held at $\mathrm{pH}=1$. After completion, the sample was filtered, washed and dried as described above. Both cellulose extraction techniques were repeated on samples that had previously undergone 15 -min boiling in $2.0 \%$ W/W NaOH.

Humate $(\mathrm{NaOH}$ soluble) fractions were retained and precipitated with $100 \mathrm{ml}$ conc $\mathrm{HCl}$. These were filtered, washed, dried and processed for dating using procedures described above.

\section{RESULTS}

Sample ${ }^{14} \mathrm{C}$ dates are listed in Table 1 and plotted in Figure 3. These dates are quoted in years BP (1950) and corrected, where possible, using the $\delta^{13} \mathrm{C}$ values normalized to $-25 \%$ o relative to the PDB standard (Stuiver \& Polach, 1977). Instrument calibration was performed with the laboratory's marble chip background and NBS oxalic acid standards. Uncertainties are based on errors in background, oxalic acid and sample measurements (Stuckenrath \& Mielke, 1972) and quoted as $\pm 1 \sigma$. The $\delta^{13} \mathrm{C}$ values are presented in Table 1 and Figure 4. (No uncertainties were given by Stable Isotope Laboratory).

There are two anomalies in the results that require special attention. PITT-9002A yielded an older date and a more negative $\delta^{13} \mathrm{C}$ value than other soluble fractions also extracted with $2.0 \% \mathrm{NaOH}$ (PITT-9003A, -9011A, -9012A, -9013A and -9017A). Given the $\delta^{13} \mathrm{C}$ value, this sample probably was contaminated. PITT-9013D is much older than any other date obtained in this study. It was the fourth humate fraction extracted and, thus, was very small. An error of this magnitude probably resulted from sample or sample gas contamination, although the possibility of instrument error cannot be ignored. The date of this sample is not included in Figure 3. 
SOLID AND SOLUBLE DATES

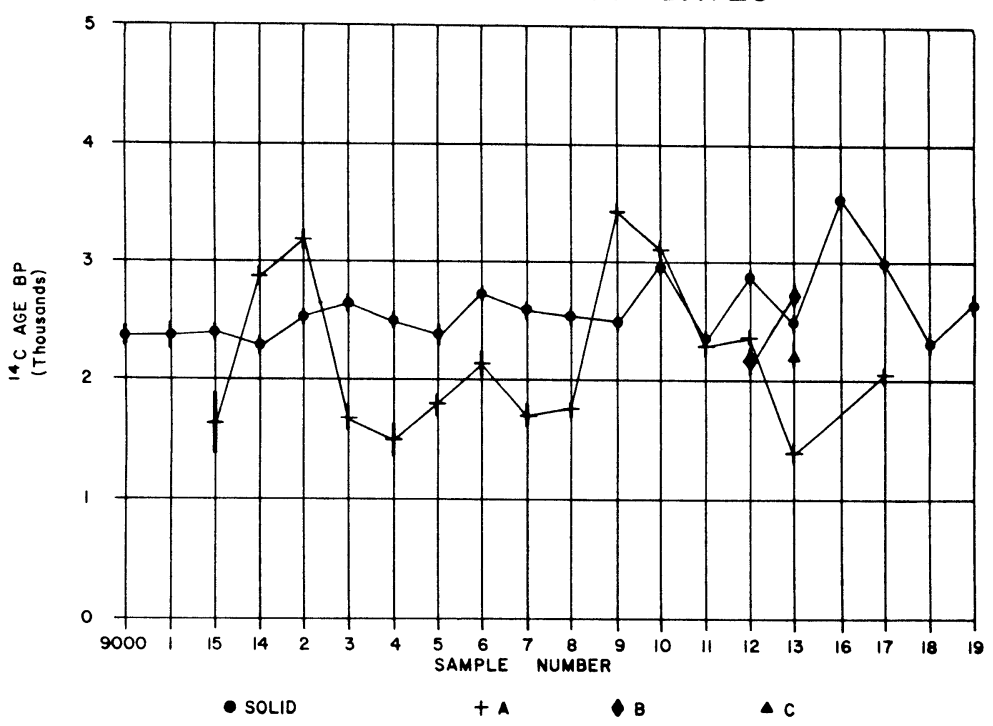

Fig 3. Comparison of ${ }^{14} \mathrm{C}$ measurements on peat samples

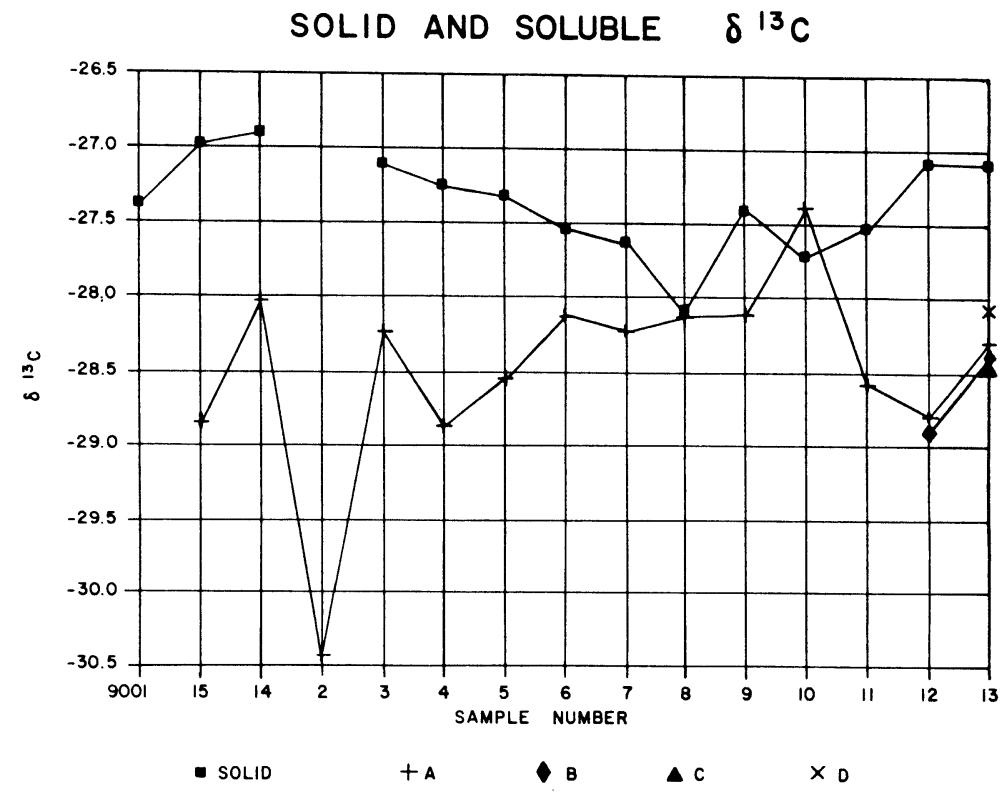

Fig 4. Comparison of $\delta^{13} \mathrm{C}$ values from peat samples 


\section{TABLE 1}

Pretreatments, ${ }^{14} \mathrm{C}$ Dates and ${ }^{13} \mathrm{C}$ Results for Freshwater Peats from Carrying Place Cove, South Lubec, Maine

\begin{tabular}{|c|c|c|c|c|c|c|}
\hline Pretreatment & PITT & ${ }^{14} \mathrm{C}$ Age & $\partial^{13} \mathrm{C}$ & Fraction & ${ }^{14} \mathrm{C}$ Age & $\partial^{13} \mathrm{C}$ \\
\hline None & -9000 & $2360 \pm 90$ & $\bullet$ & None & & \\
\hline $2 . \mathrm{ON} \mathrm{HCl}$ & -9001 & $2370 \pm 80$ & -27.36 & None & & \\
\hline Boil $0.1 \% \mathrm{NaOH}, 2.0 \mathrm{~N} \mathrm{HCl}$ & -9015 & $2390 \pm 45$ & -26.98 & $\mathbf{A}$ & $1640 \pm 220$ & -28.84 \\
\hline Boil $1.0 \% \mathrm{NaOH}, 2.0 \mathrm{~N} \mathrm{HCl}$ & -9014 & $2270 \pm 60$ & -26.89 & $\mathbf{A}$ & $2870 \pm 70$ & -28.03 \\
\hline Boil $2.0 \% \mathrm{NaOH}$, no acid treatment & -9002 & $2530 \pm 60$ & $*$ & $\mathbf{A}$ & $3180 \pm 80$ & -30.42 \\
\hline Boil $2.0 \% \mathrm{NaOH}, 2.0 \mathrm{~N} \mathrm{HCl}$ & -9003 & $2640 \pm 60$ & -27.12 & $\mathbf{A}$ & $1670 \pm 120$ & -28.23 \\
\hline Boil $4.0 \% \mathrm{NaOH}, 2.0 \mathrm{H} \mathrm{HCl}$ & -9004 & $2520 \pm 35$ & -27.24 & $\mathbf{A}$ & $1480 \pm 150$ & -28.88 \\
\hline Boil $6.0 \% \mathrm{NaOH}, 2.0 \mathrm{~N} \mathrm{HCl}$ & -9005 & $2370 \pm 80$ & -27.30 & $\mathbf{A}$ & $1820 \pm 70$ & -28.54 \\
\hline Boil $8.0 \%, \mathrm{NaOH}, 2 . \mathrm{ON} \mathrm{HCl}$ & -9006 & $2760 \pm 40$ & -27.55 & $\mathbf{A}$ & $2140 \pm 110$ & -28.12 \\
\hline Boil $10.0 \% \mathrm{NaOH}, 2.0 \mathrm{~N} \mathrm{HCl}$ & -9007 & $2590 \pm 80$ & -27.63 & $\mathbf{A}$ & $1720 \pm 120$ & -28.23 \\
\hline Boil $12.0 \% \mathrm{NaOH}, 2.0 \mathrm{~N} \mathrm{HCl}$ & -9008 & $2540 \pm 70$ & -28.09 & $\mathbf{A}$ & $1770 \pm 40$ & -28.11 \\
\hline Boil $2.0 \% \mathrm{NaOH}$ ( 3 hours), $2.0 \mathrm{~N} \mathrm{HCl}$ & -9009 & $2490 \pm 60$ & -27.40 & $\mathbf{A}$ & $3430 \pm 60$ & -28.11 \\
\hline Boil $2.0 \% \mathrm{NaOH}$ ( 6 hours), $2.0 \mathrm{~N} \mathrm{HCl}$ & -9010 & $2990 \pm 40$ & -27.71 & $\mathbf{A}$ & $3090 \pm 40$ & -27.38 \\
\hline Boil $2.0 \% \mathrm{NaOH}$, centrifuge, $2.0 \mathrm{~N} \mathrm{HCl}$ & -9011 & $2320 \pm 40$ & -27.53 & $\mathbf{A}$ & $2280 \pm 80$ & -28.57 \\
\hline Boil $2.0 \% \mathrm{NaOH}$, centrifuge, wash with & -9012 & $2900 \pm 50$ & -27.08 & $\mathbf{A}$ & $2360 \pm 80$ & -28.80 \\
\hline $\begin{array}{l}500 \mathrm{ml} \text { deionized } \mathrm{H}_{2} \mathrm{O} \text {, centrifuge, } \\
2.0 \mathrm{~N} \mathrm{HCl}\end{array}$ & & & & B & $2180 \pm 80$ & -28.85 \\
\hline Boil 1 repetitions with $2.0 \% \mathrm{NaOH}$ & -9013 & $2450 \pm 80$ & -27.08 & $\mathbf{A}$ & $1400 \pm 70$ & -28.29 \\
\hline removing soluble fraction after each & & & & $\mathbf{B}$ & $2750 \pm 80$ & -28.37 \\
\hline \multirow[t]{2}{*}{ boil, $2.0 \mathrm{~N} \mathrm{HCl}$} & & & & $\mathbf{C}$ & $2240 \pm 110$ & -28.38 \\
\hline & & & & D & $7310 \pm 290$ & -28.07 \\
\hline Cellulose extraction with $\mathrm{NaClO}_{2}$ & -9016 & $3570 \pm 60$ & $*$ & & & \\
\hline $\begin{array}{l}\text { Cellulose extraction with } \mathrm{NaClO}_{2} \text { after } \\
\text { boil } 2.0 \% \mathrm{NaOH}\end{array}$ & -9017 & $2980 \pm 80$ & $*$ & $\mathbf{A}$ & $2060 \pm 45$ & \\
\hline Cellulose extraction with $\mathrm{NaClO}$ & -9018 & $2270 \pm 80$ & $* *$ & None & & \\
\hline $\begin{array}{l}\text { Cellulose extraction with } \mathrm{NaClO} \text { after } \\
\text { boil } 2.0 \% \mathrm{NaOH}\end{array}$ & -9019 & $2670 \pm 80$ & $* *$ & None & & \\
\hline
\end{tabular}

*Mass spectrometer sample unsuitable for analysis.

* Mass spectrometer data not received.

\section{DISCUSSION}

The first four samples in Table 1 (PITT-9000 to -9001, -9014 to -9015) were younger than those samples treated with higher concentrations of $\mathrm{NaOH}$. This could be an indication that incomplete removal of humic acid occurred during extraction. The correlation between PITT-9000 to -9001 and PITT-9002 to -9003 indicates an absence of carbonate contamination in the sample material.

Although the dates do not always overlap within the given range of uncertainty, the group of samples pretreated with progressively higher con- 
centrations of $\mathrm{NaOH}$ (PITT-9003 to -9008) exhibits no general change in resultant age. The results obtained by varying time of extraction, number of extractions and washing techniques are ambiguous but some increases in sample age (PITT-9010 and -9012) are noted. The younger age of PITT9011 is probably due to incomplete removal of humates by the centrifuge separation method.

Cellulose extraction using $\mathrm{NaClO}_{2}$ does yield older dates for both PITT-9016 and -9017, but it is puzzling that PITT-9017, which had previously undergone humate extraction, dated younger. The extraction with $\mathrm{NAClO}$ appears ineffective, since the dates correspond with those obtained from samples subjected to identical or no humate extraction (PITT-9003, $-9000)$.

The results from the soluble fractions are, with the exceptions of PITT9009A, -9010A and -9014A, younger than the corresponding solid samples. The dates do not seem to mimic trends seen in the solid sample date and exhibit little agreement even among samples pretreated using identical methods (PITT-9003A, -9011A, -9012A, -9013A and -9017A). The $\delta^{13} \mathrm{C}$ values for the soluble fractions are, with the exception of PITT-9010A, more negative than the corresponding values for solid samples.

Generally, results indicate that for this type of material, the solid fraction is more suitable for ${ }^{14} \mathrm{C}$ analysis. If humate extraction methods are used, an $\mathrm{NaOH}$ concentration of $2.0 \%$ is adequate for complete removal. Cellulose extraction with $\mathrm{NaClO}_{2}$ does remove younger contaminates, but this method is expensive in terms of both time and the amount of reagent required.

\section{ACKNOWLEDGMENTS}

The author would like to thank $\mathrm{H} \mathrm{W}$ Borns, Jr and his associates at the University of Maine, Orono, for collection of the sample material and onsite observations. Thanks are also extended to Robert Stuckenrath for his support and assistance during this project.

\section{REFERENCES}

Kigoshi, K, Suzuki, N and Shiraki, M, 1980, Soil dating by fractional extraction of humic acid, in Stuiver, M, and Kra, R S, eds, Internatl ${ }^{14} \mathrm{C}$ conf, 10th, Proc: Radiocarbon, v 22, no. 3, p 853-857.

Polach, $\mathrm{H}$ and Singh, G, 1980, Contemporary ${ }^{14} \mathrm{C}$ levels and their significance to sedimentary history of Bega swamp, New South Wales, in Stuiver M, and Kra, R S, eds, Internatl ${ }^{14} \mathrm{C}$ conf, 10th Proc: Radiocarbon, v 22, no. 2, p 398-409.

Stuckenrath, R and Mielke, J E, 1972, Smithsonian Institution radiocarbon measurements VII: Radiocarbon, v 19, no. 3, p 401-412.

Stuiver, M and Polach, H A, 1977, Discussion: Reporting of ${ }^{14} \mathrm{C}$ data: Radiocarbon, v 19, no. 3 , p 355-363. 